\title{
IN SEARCH OF EFFECTIVE PROFESSIONAL DEVELOPMENT OF EFL TEACHERS IN VIETNAM
}

\author{
Truong Vien* \\ College of Foreign Languages, Hue University, 57 Nguyen Khoa Chiem, An Cuu, Hue, Vietnam
}

Received 22 March 2017

Revised 10 May 2017; Accepted 18 May 2017

\begin{abstract}
Professional development (PD) plays an important role in maintaining and improving teachers' qualities and competences, but how to make a PD program effective in relation to needs in multiple contexts has still been a matter of much concern by administrators, researchers, and teachers alike. This paper therefore aims to deal with this issue with a view to assisting EFL teachers to develop their PD in an effective way. At first, the paper points out necessity of PD and some weaknesses in PD plans from EFL environments in Vietnam and uses them as rationale for discussion in the following parts. Then it starts xthe discussion by defining the concepts of PD and effective PD by different scholars that reflect the current trend of individualized and school-based PD, and presenting scientific evidence about characteristics of effective PD programs in the literature. From this scientific foundation, the paper finally makes suggestions about how an effective PD program for EFL teachers and by EFL teachers should be designed and implemented in the Vietnamese context with sufficient attention to contextual factors.
\end{abstract}

Keywords: effective professional development plan, needs, PD tools, characteristics, EFL in-service teacher, research-based, school-based

\section{Introduction}

The fact that English has been one of the most popular languages in the world is taken for granted. In the Vietnamese context, the English language has become the first foreign language in schools and universities (Le, 2002). Recently, the government has released a number of policies to improve quality of English instruction at all levels, and priority is given to language teacher profession. As a result, many professional development (PD) programs to improve competences of subject matter and methodology of in-service EFL teachers by Ministry of Education and Training (MoET) have been operated to meet the ever-increasing demands of EFL instruction in Vietnam.

\footnotetext{
* Tel.: 84-913427114

Email: truongviensp@gmail.com
}

In the Decision on the approval of the National Foreign Languages 2020 Project, in dealing with PD-related tasks, the government focuses on establishing Management Board from Central Government; organizing the implementation of examination, re-planning; constructing training and re-training plans; and setting up continuation training (Nguyen, 2008). This shows the government's determination to improve the quality of teaching and learning EFL, in which professional development and PD programs are among the foci.

Nguyen (2013a, 2013b), who is from the NFL2020 Project, when reviewing the instruction of EFL at secondary schools reported from a survey that $87 \%$ of lower secondary school teachers and about $92 \%$ of upper secondary school teachers were underqualified to teach English, and that they 
would be exposed to such domains as ELT methodology, knowledge of language learners, professional attitudes and values, and practice and context of language teaching (Nguyen, 2013a). In a recent survey on most-wanted qualities of English teachers by 339 students at English centers from nine cities in South Vietnam, 12 qualities of English teachers are supposed to influence students' learning, the first six qualities include English competence, ability to apply teaching principles, ability to manage the class, personal attributes, ability to meet students' learning needs, and ability to use effective assessment (Tran, 2015). These studies significantly revealed issues in improving EFL teachers' qualities.

Reality also shows that, even though some positive results have been found, a number of issues in the field of professional development revealed through recent $\mathrm{PD}$ programs in Vietnam need to be dealt with. First and foremost, in terms of PD management, human resource managers in the field of language teacher education and development should be considered in universities (Tran, 2009). These managers, who are expected to prepare and provide best conditions for teachers to fully improve and develop their occupation, should have profound knowledge of teacher career advancement and thorough understanding of inter-related issues concerning teacher professional development. Secondly, language teachers at secondary schools were not given adequate training in TEFL so as to catch up with modern teaching methodology (Pham, 2001). One possible cause is that there was a missing link between training and the reality where trainee teachers would be expected to work (Le, 2002). Thirdly, regarding the recent professional development programs, many administrators said that these programs were mostly prescribed from above, short-term and unsystematic, and they did not include followup activities (Hong Hanh, 2016). Finally, in several schools, teachers were only familiar with class observation as an essential PD activity, and sadly enough, many teachers did not conduct this activity in an organized and effective way (Truong, 2013). Most of these teachers also stated that they needed more insights into such PD tools as reflective teaching, action research, mentoring, peer coaching, teaching journal, PD portfolios, and developing individual PD plan.

From the overview of PD necessity and reality in Vietnam, it is necessary, therefore, to reexamine the concept of effective professional development and what a PD program should be like from the current research studies, and how it should be implemented in EFL settings like Vietnam.

\section{What is professional development?}

Before exploring what effective professional development is, we should take a look at some definitions of professional development nowadays in the literature. Different views of PD may lead to different implementation of PD strategies.

Traditionally, teacher development is viewed as special and short-term events, including one-shot workshops, presentations, or graduate courses that teachers follow during their career to update their knowledge (Birman et al., 2000). This viewpoint makes professional development restricted to purely the activities that are designed and offered by educational institutions, and PD is therefore prescriptive, short-term, segmental, and incoherent in terms of teachers' needs and previous or current knowledge.

To many scholars, teacher development is a term used in the literature to describe a process of continual intellectual, experimental, and attitudinal growth on the part of teachers. $\mathrm{PD}$ is defined as an on-going learning process in which teachers engage voluntarily to 
learn how to best adjust their teaching to the needs of their students (Guskey, 2000; DiazMaggioli, 2003). Diaz-Maggioli (2003, p.1) defined professional development as follows:

"Professional development is not a one-shot, one-size-fits-all event, but rather an evolving process of professional selfdisclosure, reflection, and growth that yields the best results when sustained over time in communities of practice and when focused on job-imbedded responsibilities."

Day (1999, p.4) gives us a broader definition about professional development:

"Teacher professional development consists of all natural learning experiences and those conscious and planned activities which are intended to be of direct or indirect benefit to the individual, group, or school and [...] through this, to the quality of education in the classroom. It is the process by which, alone and with others, teachers review, renew and extend their commitment as change agents to the moral purposes of teaching: and by which they acquire and develop critically the knowledge, skills and emotional intelligence essential to good professional thinking, planning and practice with children, young people and colleagues..."

Day's definition shows that professional development is a complex, constant, and longterm process which aims at both intellectual and emotional change on the part of the teachers to maintain or raise the quality of education in classroom. It may be conducted alone or in collaboration with others, and it includes events that happen outside the intention of teachers and institutions but lead to an improvement in teachers' knowledge, skills and practice. Day's viewpoint (1999) on PD, together with those of Guskey (2000), and Diaz-Maggioli (2003) reflects current beliefs of most scholars in the field, especially through approaches to research studies, which also lays a scientific foundation of this paper.

\section{Effective Professional Development}

In dealing with effective professional development for language teachers, Richardson (2003, p. 402) stated that it should be:

"statewide, long term with follow-up; encourage collegiality; foster agreement among participants on goals and visions; have a supportive administration; have access to adequate funds for materials, outside speakers, substitute teachers, and so on; encourage and develop agreement among participants; acknowledge participants existing beliefs and practices; and make use of outside facilitator/staff developers."

Desimone (2011) suggested five features of effective PD that need to be considered: (a) content focus: activities that are focused on subject matter content and how students learn that content; (b) active learning: opportunities for teachers to observe, receive feedback, analyze student work, or make presentations, as opposed to passively listening to lectures; (c) coherence: content, goals, and activities that are consistent with the school curriculum and goals, teacher knowledge and beliefs, the needs of students, and school, district, and state reforms and policies; (d) sustained duration: PD activities that are ongoing throughout the school year and include 20 hours or more of contact time; and (e) collective participation: groups of teachers from the same grade, subject, or school participate in PD activities together to build an interactive learning community.

In his recent effort of analyzing 13 different lists of the characteristics of effective professional development from different disciplines, all published within the last decade, Guskey (2003) discovered that they were derived in very different ways, used different criteria to determine "effectiveness", and that these characteristics are multiple and rather complex. In most of the lists, 
however, the frequently cited characteristics include enhancement of teachers' content and pedagogical knowledge, provision of sufficient time and other resources as essential to effective PD, promotion of collegiality and collaborative exchange, inclusion of evaluation procedures, school- or site-based consideration, and emphasis on student performance (Guskey, 2003).

In general, when dealing with effective professional development, most experts in the field advocate moving away from an inservice training model where teachers are expected to learn a clearly defined body of skills through one-shot workshops or courses taught away from the school premises to models that are grounded in classroom practice and other aspects of school change, involve the formation of professional learning communities, employ different modes of input delivery, sustain over time and in a coherent manner, promote teachers' change and growth, and gear teachers' practices towards students learning. The following twelve research-based characteristics compiled from the literature by the author and presented in terms of content and form, are supposed to reflect the current trend of effective PD in the literature and be closely related to the reality of professional development of EFL teachers in Vietnam.

\section{Content}

Content and pedagogy: Teachers' content and pedagogical knowledge should be continuously enhanced. Teachers should be helped to understand more deeply the content they teach and the ways students learn that content appear to be a vital dimension of effective professional development (Birman, 2000; Nguyen, 2013a). A PD activity shows to be effective in improving teachers' knowledge and skills if it forms a coherent part of a wider set of opportunities for teacher learning and development, builds on previous knowledge, supports national and provincial standards and assessment, and is consistent with teacher goals (Birman, 2000).

Situating needs in multiple contexts: Professional development should address teachers' needs, and be situated in multiple contexts, both in schools and offsite, integrating teachers' and schools' needs as well as national demands to transfer recent international innovations in the field (Borko, Jacobs, \& Koellner, 2010). The design of an effective professional development program should be grounded not only in a conception of how individual teachers learn, but also in a conception of how schools as organizations affect, and are affected by, teachers' learning (King \& Newman, 2001). Collective participation, i.e. teachers from the same school, department, or grade level joining a professional development program, shows to be useful in terms of discussing concepts, skills and problems in the same context, sharing common issues related to curriculum instruction, dealing with students' needs across classes and grade levels, and contributing to a shared professional culture (Birman et al., 2000).

Focusing on student learning: Effective professional development has to show improvements in student learning outcomes. These outcomes should be broadly defined to include a variety of indicators of student achievement, such as assessment results, portfolio evaluations, marks or grades, or scores from standardized examinations. Affective outcomes such as students' attitudes, attendance rates, dropout statistics, and participation in school activities should also be considered (Guskey, 2003). If a professional development program exerts a direct influence on students' behaviours, this will encourage teachers to view the program positively (Daloglu, 2004). 
Addressing teacher change: Effective professional development should lead to teacher change in cognition, beliefs, attitude, and practice (Ermeling, 2010; Gersten et al., 1997, cited in Avalos, 2011). Besides, professional development program for language teachers helped teachers to grow professionally in terms of how to develop effective language teaching materials, curriculum related issues, teacher collaboration, self-confidence as a learner (Daloglu, 2004). In addition, action research showed to affect areas of teacher recognition such as norms and values, connection between phenomena, and methods (Ponte et al. 2004).

\section{Form}

Duration: Professional development requires considerable time, and that time must be well-organized, carefully structured, purposefully directed, and focused on content or pedagogy or both (Birman et al., 2000). The length of one full academic year shows to be appropriate since this length of time will help teachers have a chance to learn, implement, relearn, reimplement, forming a cycle of experimentation especially in getting feedback on what teachers have learned and produced (Daloglu, 2004).

Collaboration and school-based PD communities: Collegiality and collaborative exchange should be promoted to make professional development effective. Teachers and educators at all levels value opportunities to work together, reflect on their practices, exchange ideas, and share strategies. They may try out new ideas in classrooms and monitor the success of their efforts (Englert \& Tarrant, 1995). Professional development may be better when teachers and researchers collaborate to examine and reflect on practice, both are involved in co-constructing formal and practical knowledge (Bos, 1995).
Professional development needs to be focused on building up PD communities within schools for teachers to interact for their current as well as life-long teaching activities (Rueda, 1998; Matsumura and Steinberg, 2002).

Self-regulation:

Professional development will be effective if the learning processes of the teachers working within collaborative communities are also focused on. If teachers are supported to self-regulate their learning about teaching, then they will be able to help students to control such selfregulated learning activities, interpreting tasks to define learning goals, selecting, adapting, or even inventing strategic approaches to achieve desired outcomes, reflecting on progress and self-assessing performance, and revising learning approaches adaptively (Butler \& Winne, 1995). Teachers should therefore be encouraged to design self-regulated activities in their collaborative professional development plan for effective professional development (Butler \& Winne, 1995).

Technology-mediated input delivery and PD activities: Teachers should be trained and encouraged to make use of technology for their professional development, since many new PD models are incorporating various technology-related components, including digital libraries, web-based virtual learning environments and online and electronic conferencing features. These technologies are supposed to overcome time and place constraints and provide the means to reach large numbers of individual teachers at costs lower than those associated with the physical presence of professional development personnel (Rennie, 2001). Hybrid PD models that feature both online communication (either asynchronous or synchronous) and face-toface components are gaining in popularity (Borko et al., 2010). Online collaboration for PD showed to help teachers in one institution with experiences such as envisioning 
professional development, gaining and enhancing skills, sharing and exchanging, and socializing (Kabilan et al. 2011).

In designing a PD program, such issues as how it was delivered, the nature of the activities that were pursued, types of PD tools practiced, duration of the activities, should be considered (Kimberly et al. 2007). Careful adaptation to specific content, process, and context elements showed to be of great importance.

Volunteer basis: Effective professional development should be implemented on a volunteer basis (Bobrowsky, Marx, \& Fishman, 2001, cited in Kimberly et al, 2007). Volunteers differ from non-volunteers in terms of their motivation to learn, their commitment to change, and their willingness to be risk takers (Loughran \& Gunstone, 1997, cited in Kimberly et al, 2007).

PD management unit: In making professional development effective, there should be a unit in the national or provincial institutions in charge of this domain (Tran, 2009). Those responsible for planning and implementing professional development must learn how to critically assess and evaluate the effectiveness of what they do. In addition, there should be discussions about the specific goals of professional development, what evidence best reflects the achievement of these goals, and how that evidence can be gathered in meaningful and scientifically defensible ways must become the starting points for all planning activities (Guskey, 2000)

Follow-up: Teachers at all levels need just-in-time, job-imbedded assistance as they struggle to adapt new curricula and new instructional practices gained from workshops to their unique classroom contexts. All of the studies that showed positive improvements in student learning included significant amounts of structured and sustained follow-up after the main professional development activities (Guskey \& Yoon, 2009).
Leadership and school support: To make PD activities more school-based, pedagogical leadership in supporting teachers' development such as the importance of principals' provision of pedagogical leadership on a larger scale also needs consideration when planning and implementing these programs (Daloglu, 2004). The support provided by the school such as reducing teaching timetable or secretarial support encouraged teachers to devote their time and energy to a professional development program.

\section{Suggestions for effective $P D$ in the Vietnamese context}

The following suggestions are generally based on the characteristics of effective professional development mentioned above with reference to contextual factors in Vietnam and aim to assist PD planners, educators and language teachers to build up a professional development program that works for EFL teachers all through the country.

(1) Section of PD management of EFL teachers should be nationally or provincially headed by personnel who used to be experienced language teachers and researchers and who grasp current approaches to PD so as to ensure the right and proper direction of professional development policies and PD plans. In a similar way, a professional development plan for EFL teachers should be constructed collaboratively with the participation of foreign and local experts, researchers, provincial administrators, and school teachers in the field. Also, there should be constant co-operations between provincial departments of education and training and local universities/colleges of foreign languages for PD program development and implementation, and syllabus design and modification. More importantly, establishing professional development communities 
on different scales for continuous PD of EFL teachers should be a focus in national, provincial or institutional policies or plans.

(2) A professional development program should include such components as context establishment, purpose and scope of the program, identification of specific needs and expectations, structure of the program, implementation and evaluation of the program.

(3) A professional development program should be situated in terms of versatility and practicality, so that the program is sensitive to variety of contexts in Vietnam, especially school-based settings, where management boards make efforts to establish school culture, and where teachers are allowed to deal with their own needs, focus on their students' learning, be exposed to innovative approaches, and have time to participate in and reflect upon their instructional activities in an effective and organized way.

(4) There should be a combination of different formats of input delivery, employing various tools for effective professional development, and organizing time on an on-going basis. Delivery format has to be decided before planning a PD program: either online or face-to-face, or hybrid. Classroom activities have to be considered so as to develop teachers' PD capacity in an optimal way. There should be a progression from individual teachers, groups of teachers, institutions, to groups of institutions moving from awareness, to reflection on teaching, reflective teaching, and action research. Time needed for each professional development program should range from 4-6 weeks, to one semester or school year, and content of PD should be properly tailored to suit the time length.

(5) Regarding procedure of implementing a PD program, there should be a number of coherent steps, which are as follows:

- A survey should be conducted to gain topics for the program from target EFL teachers' and administrators' needs.
- After the survey, a body of trainers, foreign and local, national and regional, should sit together to develop a PD program, dealing with themes for $\mathrm{PD}$, mode of input transfer, classroom activities, trainers, duration and timetable, type of participants, and related resource preparation.

- In the initial step of the PD program, trainers should deal with local topics theoretically, give examples from research studies, and invite teachers to share their experiences from their classroom instruction.

- After this initial step, trainers may focus on national and international ELT issues by both transferring input and assisting teachers to understand the issues through activities and examples. At this stage, teacher collaboration activities as well as self-regulated plans from teachers are encouraged. They are also asked to reflect upon what they have done and achieved after each step to make sure the program is smoothly implemented.

- Teachers' PD activities related to assigned themes of a PD program or of the whole program such as reflections, journals, portfolios, have to be dealt with at the end of a program so that teachers' growth and change can be practically followed and their professional competence effectively evaluated.

- Follow-up plans should be encouraged to develop and share so that all individual participants may have common actions for further implementation. These follow-up plans should be organized with close examination of and support from provincial and local institutions.

- A formal evaluation of the professional development program should be 
conducted at the end of the program so as to gain teachers' feedback on positive and negative points of the program.

(6) Individual language teachers should be willing to build up their own PD plans that are based on national or provincial $\mathrm{PD}$ programs as well as their personal PD objectives in reference to the characteristics of effective PD mentioned above, in order to make professional development self-directed, on-going, and beneficial.

In conclusion, this paper focuses on characteristics of professional development in general and a PD program in particular, almost all of which are research-based and supposed to be related to reality of professional development of language teachers in EFL contexts like Vietnam. More significantly, some suggestions are presented with a view to making PD and PD programs in the future better, more school-based and effective.

It would be more convincing if all of these scientific characteristics were supported by empirical evidence revealed through local and national contexts in Vietnam. However, as Corcoran (2001) pointed out, school staff members often paid lip service to the use of research in classrooms and were more interested in designs that drew on research about practices. It is therefore significant to discuss the characteristics of effective PD viewed and suggested by researchers in the world and use them as starting points in planning and implementing effective professional development programs for language teachers with consideration of the contextual factors of Vietnam.

\section{References}

\section{English}

Avalos, B. (2011). Teacher professional development in Teaching and Teacher Education over ten years. Teaching and Teacher Education, 27, 10-12.
Available through $<$ http://citeseerx.ist.psu.edu/ viewdoc/download?doi=10.1.1.466.6330\&rep=rep 1\&type=pdf $>$, accessed March 9, 2017, 10:12.

Birman, B. F., L.Desimone, A. C. Porter, M. S. Garet (2000). Designing Professional Development That Works. Educational Leadership, USA. Available through < http://www.ascd.org/ASCD/pdf/journals/ ed_lead/el200005_birman.pdf $>$, accessed March 5, $2017,10: 35$.

Borko, H; J Jacobs, K Koellner (2010). Contemporary Approaches to teacher Professional Development. International Encyclopedia of Education, vol. 7, pp548556. Available through $<$ https://www.researchgate.net/ publication/242071048_Contemporary_approaches to teacher professional development>, accessed March 4, 2017, 08:43.

Bos, C. S. (1995). Professional development and teacher change. Remedial and Special Education, 16(6), 379-382. Available through < http://journals. sagepub.com/doi/abs/10.1177/07419325950160061 0>, accessed March 4, 2017, 10:15.

Butler, D. L., \& Winnie, P. H., (1995). Feedback and self-regulated learning: A theoretical synthesis. Review of Educational Research, 65, 245-281. Available through <http://journals.sagepub.com/ doi/pdf/10.3102/00346543065003245>, accessed March 4, 2017, 09:13.

Cárdenas, M. L. (2003). Teacher researchers as writers: A way to sharing Findings. Colombian Applied Linguistics Journal 5, 49-64. Available through $<$ ww.scielo.org.co/scielo.php?script $=$ sci_arttext\&p $\mathrm{id}=$ S0123-46412003000100004>, accessed March 6, 2017, 08:16.

Corcoran, Thomas B., Susan H. Fuhrman, and C.L. Belcher (2001). "The District Role in Instructional Improvement. " Phi Delta Kappan 83, September: 7884. Available through http://repository.upenn.edu/ cgi/viewcontent.cgi article $=1006 \&$ context $=$ gse_ pubs, accessed March 4, 2017, 07:16.

Daloglu, A. (2004). A professional development program for primary school English language teachers in Turkey: Designing a material bank. Elsevier Ltd. Available through < http:/www.sciencedirect.com/ science/article/pii/S0738059304000513>, accessed March 5, 2017, 09:34.

Day, C. (1999). Developing teachers: Challenges of lifelong learning. London: Falmer Press. Available through < http://files.eric.ed.gov/fulltext/ED434878. pdf, accessed March 7, 2017, 09:17.

Desimone, L. M., (2011). A Primer on Effective Professional Development. Phi Delta Kappan 92, No 6. Available through < file://C:/Users/USER/ Downloads/0ef4ad96ec3ed85914b5f0a64f6a73d3 6e04.pdf>, accessed March 5, 2017, 12:15.

Diaz-Maggioli, G. H. (2003). Professional Development for Language Teachers. Available through http://unitus.org/FULL/0303diaz.pdf, accessed March 13, 2017, 09:12. 
Englert, C. S., \& Tarrant, K. L. (1995). Creating Collaborative cultures for educational change. Remedial \& Special Education, 16(6), 325-336. Available through < http://journals.sagepub.com/ doi/pdf/10.1177/074193259501600602>, accessed March 10, 2017, 10:12.

Guskey, T.R. (2000). Evaluating Professional Development. Thousand Oaks, CA: Corwin.

Guskey, T.R. (2003). What Makes Professional Development Effective? Chicago. Available through $<$ http://journals.sagepub.com/doi/abs/10.1177/003 172170308401007?journalCode $=$ pdka $>, \quad$ accessed March 9, 2017, 10:12.

Guskey, T. R., \& Yoon, K. S. (2009) What Works in Professional Development? Washington DC.Available through < http://www.k12.wa.us/ Compensation/pubdocs/Guskey2009whatworks. pdf $>$, accessed March 10, 2017, 10:14.

Kabilan, M. K., Adlina, W. F. W., Embi, M. A., (2011). Online collaboration of English language teachers for meaningful professional development experiences. English teaching practice and critique, Vol. 10, No. 4, pp94-115. Available through https:// eric.ed.gov/?id=EJ962608, accessed March 5, 2017, 10:12.

Kimberly, A. L. \& Pellegrino, J. W. (2007). Professional development in integrating teachnology into teaching and learning: Knows, Unknowns, and Ways to Pursue Better Questions and Answers. Review of Educational research, Vol. 77, No4, 575614. Available through $<$ https://www.researchgate. net/publication/249797960_Professional Development_in_Integrating_Technology_Into Teaching and Learning Knowns Unknowns and_Ways_to_Pursue_Better_Questions_and Answers>, accessed March 13, 2017, 10:12.

King, M. B., \& Newman, F. M.(2001). Building school capacity through professional development: conceptual and empirical considerations. The International Journal of Educational management, 15/2, 86-93. Available through < http://www.emeraldinsight.com/doi/ abs/10.1108/09513540110383818>, accessed March 7, 2017, 10:23.

Le Van Canh (2002). Sustainable Professional Development of EFL Teachers in Vietnam. Teacher's Edition, November.

Matsumura, L. C.; Steinberg, J. R. (2002). Collaborative, School-based Professional Development Settings for teachers: Implementation and Links to improving the quality of classroom practice and student learning. The Regents of the University of California. Available through < http://cresst.org/ publications/cresst-publication-2940/>, accessed March 7, 2017, 10:15.

Nguyen Ngoc Hung (2013a). Chapter 1.7 Vietnam's National Foreign Language 2020 Project: Challenges, Opportunities, and Solutions. Available through http://bruneiusprogramme.org/wp-content/ uploads/2013-Forum-Publication-Complete.63-65. pdf, accessed March 12, 2017, 10:49.

Nguyen Ngoc Hung (2013b). National Foreign Language 2020 Project Presentation at Vietnam Engineering Education Conference. Cantho University, March 20. Available through http://36 mfjx1a0yt01 ki78v3bb46n15gp.wpengine.netdnacdn.com/wp-content/uploads/2013/07/130319-20NNH-National-Foreign-Languages-2020-ProjectPresentation-at-Vietnam, accessed March 12, 2017, 10:55.

Nguyen Thien Nhan (2008). DECISION on the Approval of the Project entitled "Teaching and Learning Foreign Languages in the National Education System, Period 2008-2020. Available through http://d13km0x9ddrpfq.cloudfront.net/iwtcore/ uploads/2012/08/1-3Decision_1400_QD-TTg-Eng. pdf, accessed March 12, 2017, 11:12.

Pham Hoa Hiep (2001). Teacher Development: A real need for English departments in Vietnam. English Teaching Forum, October.

Ponte, P, Ax, J, Beijaard, D., \& Wubbels, T. (2004). Teachers' development of professional knowledge through action research and the facilitation of this by teacher educators. Teaching and teacher Education, 20(6), 571-588. Available through < http:/www.sciencedirect.com/science/article/pii/ S0742051X04000629>, accessed March 6, 2017, 07:16.

Richardson, V. (2003). The Dilemmas of professional development. Phi Delta Kappan, 84 (5), 401-406. Available through <http:// www.gtlcenter.org/sites/default/files/docs/pa/3 PDPartnershipsandStandards/DilemmasofPD.pdf $>$, accessed March 9, 2017, 11:12.

Rueda, R. (1998). Standards for Professional Development: A Sociocultural Perspective. Online Resources: Digests Research Brief \#2 EDOFL-99-08, available through http://www.cal. org/ resources/digest/profdvpt.html accessed April 3, 2017 08:43.

Stein, M.K., Smith, M. S., and Silver, E. A. (1999). The development of professional developers: Learning to assist teachers in new settings in new ways. Harvard Educational Review 69(3), 237-269. Available through < https://www.researchgate.net/ publication/279889644_The_Development_of_ Professional Developers Learning to Assist Teachers_in_New_Settings_in_New_Ways $>$, accessed March9, 2017, 10:47.

Tran Hien (2009). Towards an Effective Teachers Professional Development in DFLSP - CFL - VNU. Available through <http://creativecommons.org/ licenses/by/3.0/>, accessed April 3, 2017, 08:51.

Tran Le Huu Nghia (2015). Vietnamese Students' Perceptions of English Teacher Qualities: Implications for Teacher Professional Development. 
University of Melbourne. Available through $<\mathrm{http}: / /$ www.academicresearchjournals.org/IJARER/index. htm>, accessed March 8, 2017, 11:30.

Truong Vien (2013). Professional Development in EFL Contexts: Perceptions and Practice, Research report, presented at TESOL International Convention 2013, 20-23 March, Dallas, Texas, USA.

\section{Vietnamese}

Hong Hanh (2016). Bồi dương Giáo viên phải có tính thưcc tế. Truy cập lúc 9:30 ngày 3/2/2017, tại http://dantri.com.vn/giao-duc-khuyen-hoc/boiduong-giao-vien-ngoai-ngu-phai-co-tinh-thucte-20160918101104666.htm.

\title{
PHÁT TRIỂN NGHIỆP VỤ HIỆU QUẢ ĐỐI VỚI GIÁO VIÊN TIẾNG ANH TẠI VIẸTT NAM
}

\author{
Trương Viên \\ Truò̀ng Đại học Ngoại ngũu, Đại học Huế, \\ 57 Nguyễn Khoa Chiêm, phuoòng An Cựu, TP. Huế, Việt Nam
}

Tóm tắt: Phát triển nghiệp vụ (PTNV) đóng một vai trò quan trọng trong việc duy trì và nâng cao phẩm chất và năng lực của người giáo viên, nhưng làm thế nào để cho một chương trình phát triển nghiệp vụ có hiệu quả so với những nhu cầu trong một bối cảnh đa dạng cho đến nay vẫn là một vấn đề được nhiều nhà quản lý, nhà nghiên cứu, và giáo viên quan tâm. Bài nghiên cứu này bàn đến vấn đề PTNV với mong muốn trợ giúp giáo viên tiếng Anh phát triển nghiệp vụ của mình một cách hiệu quả. Đầu tiên, bài nghiên cứu chỉ ra sự cần thiết của việc PTNV, những điểm yếu trong các chương trình PTNV đối với giáo viên tiếng Anh phổ thông tại Việt Nam và coi đây là lý do cho việc thảo luận ở những phần kế tiếp. Tiếp đến, bài nghiên cứu bắt đầu việc thảo luận bằng cách định nghĩa những khái niệm PTNV và PTNV hiệu quả bởi các học giả khác nhau theo các khuynh hướng hiện nay, và trình bày các bằng chứng khoa học về những đặc điểm của các chương trình PTNV hiệu quả thông qua các nghiên cứu trên thế giới và trong nước đối với lĩnh vực chuyên môn này. Trên cơ sở các đặc điểm khoa học đã nêu, bài nghiên cứu đưa ra những đề xuất về nội dung và cách thức thiết kế và tiến hành một chương trình PTNV hiệu quả đối với giáo viên tiếng Anh phổ thông tại Việt Nam, trong đó chú ý đến các yếu tố ngữ cảnh.

Từ khóa: chương trình phát triển nghiệp vụ, hiệu quả, nhu cầu, công cụ PTNV, đặc điểm, giáo viên tiếng Anh 